\title{
Correction to: Improving Underestimation of HIV Prevalence in Surveys Using Time-Location Sampling
}

\author{
Ana B. Barros • Maria Rosario O. Martins
}

Published online: 19 March 2021

(C) The New York Academy of Medicine 2021

\section{Correction to: J Urban Health \\ https://doi.org/10.1007/s11524-019-00415-8}

There were the following errors in this article as originally published:

In Equation 3, there was an opening parenthesis covering the entire left side of the equation rather than just the numerator.

In the Results, there was no space between the legend abbreviations and the explanations of what the abbreviations mean.

The original article has been corrected.

Publisher's Note Springer Nature remains neutral with regard to jurisdictional claims in published maps and institutional affiliations.

The online version of the original article can be found at https://doi.org/10.1007/s11524-019-00415-8

\footnotetext{
A. B. Barros $(\bowtie) \cdot$ M. R. O. Martins

Global Health and Tropical Medicine, Instituto de Higiene eMedicina Tropical, Universidade Nova de Lisboa, Rua daJunqueira, 100, 1349-008 Lisbon, Portugal

e-mail: anabdebarros@gmail.com

e-mail: ana.barros@ihmt.unl.pt
} 